DOI: 10.15170/DIKE.2019.03.01.05

PhD Student

SZTE ÁJTK

\title{
Comparison of Wedding Donations in Hungarian Law and Mahr in Islamic Law
}

The following study compares the Hungarian regulation of wedding donations in different ages with the legal institution of mahr in Islamic law, which continues to be considered an obligatory element of Islamic marriage to the present day. The mahr, which has to be paid by the groom to the bride, has a living tradition in today's Muslim communities. Older Hungarian regulations, mainly based on civil law proposals, drafts and articles, include the concept of the wedding gift (that the groom gave to the bride), the dowry (that the woman brought to the marriage) and the dos (reward for the loyal wife). Currently there is no legal institution similar to the mahr in Hungarian family law, as current Hungarian law treats parties to be married and spouses as equal parties in all aspects. However, in the past, wedding donations regulated by law were seen as essential elements of marriage, and they played a significant role in Hungarian society until the middle of the $20^{\text {th }}$ century, with their purpose and function being almost the same as that of the mahr.

Keywords: dos, dowry, mahr, wedding donations, wedding gift

\section{Introduction}

In my study, I compare the Hungarian regulation of wedding donations in different ages with the legal institution of mabr in Islamic law, which continues to be considered an obligatory element of Islamic marriage to the present day. Although nowadays there is no legal institution similar to the mabr in Hungarian family law, since the law of marriage in Hungary treats parties to be married and spouses as equal parties in all aspects, wedding donations regulated by law were seen as essential elements of marriage, and played a significant role in Hungarian society for centuries.

As a starting point, Malinowski's theory of cultural functionalism is worth mentioning. According to Malinowski, "culture is essentially an instrumental apparatus by which man is put in a position the better to cope with the concrete specific problems that face him in his environment in the course of the satisfaction of his needs. It is a system of objects, activities, and attitudes in which every part exists as a means to an end. Such activities, attitudes and objects are organized around important and vital tasks into institutions such as the family, the clan, the local community, the tribe, and the organized teams of economic cooperation, political, legal, and educational activity." "1 Every social institution meets a need. Based on the above assumptions, the same social institution can develop in any society in response to any need. In old Hungarian society and in the Islamic world, the woman was viewed as the more vulnerable party in a marriage, whose primary task was to run the household and educate the children, while not having an own income. In case her marriage was to be dissolved, society had to take care of the woman's livelihood. Thus,

\footnotetext{
${ }^{1}$ MALINOWSKI, A Scientific Theory of Culture and Other Essays 150.
} 
the mahr and Hungarian wedding donations to a certain extent both had the function of providing the married woman with a living in case of divorce or the death of her husband.

\section{Regulation of material benefits granted at the time of marriage in earlier Hungarian civil law}

Back in the $9^{\text {th }}$ century, the Hungarians' conquering ancestors still had the habit of kidnapping women. ${ }^{2}$ The kidnapping of women was so frequent at that time that the motif was also included in the Hungarian origin legend of the wondrous stag. The Laws of King Stephan already had a ban on kidnapping, and according to the $27^{\text {th }}$ paragraph of Stephan's Laws, marriages that came about as a result of kidnapping were not considered to be valid. ${ }^{3}$ Nevertheless, it was a living tradition in the Hungarian villages of the Carpathian Basin for a long time: in some areas of Kalotaszeg, there have recently been examples of the elopement of girls up until the mid- $20^{\text {th }}$ century. The reason for the elopement of these girls was typically that the young couple in love wanted to escape the parents' marriage plans, as the parents usually chose a suitable husband candidate for their daughter well in advance. In fact, there were also examples of elopement with the consent of the girl's parents, because in that case they did not have to give a dowry and arrange an expensive wedding. The ancient custom of kidnapping women can still be discovered in Hungarian wedding traditions today. ${ }^{4}$

In ancient Hungarian society, at the time of the conquest of the Carpathian Basin in 895$896 \mathrm{AD}$, the purchase of women was also a common practice when seeking marriage. Since on the basis of the principle of community property the groom could only have his own wealth after the foundation of his family, the fathers of the spouses agreed on the purchase price. ${ }^{5}$

Over time, due to the spread of Christianity and to Germanic influences, the purchase price paid for the woman was transformed into property given to her. The legal institution of dos (bitbér) developed from the purchase of women, and it was particularly common among the nobility. ${ }^{6}$ The dos was intended to strengthen the position of the woman, who was the more vulnerable party in the marriage in terms of property law. According to her rank, the noble woman was given dos legalis (based on customary law) or dos contractualis (included in a contract) by her husband, which in practice meant that at the time of marriage her husband set aside a part of his wealth equivalent to the former purchase price for the benefit of his wife, or more precisely for the livelihood of his future widow. ${ }^{7}$ According to Werböcay's Triple Book (Tripartitum), the woman received the dos for the loss of her virginity and for the consummation of the marriage, and she could receive it either in cash or in movable and sellable goods. According to the Golden Bull (1222), the dos was the woman's

\footnotetext{
${ }^{2}$ Hungarian Catholic Lexicon, Kidnapping of Women.

${ }^{3}$ MEZEY (ed.), Magyar jogtörténet 72.

4 SZŐCSNÉ GAZDA, A háromszéki hozomány a 19. században 23.

${ }^{5}$ BÉLI, Magyar jogtörténet. A tradicionális jog.

https://www.tankonyvtar.hu/hu/tartalom/tamop425/2011_0001_528_Beli_Gabor_Magyar_jogtortenet/ch01.html \#id51683

${ }^{6}$ HERGER, A modern magyar házassági vagyonjog 253-254.

${ }^{7}$ NAGY, A nőrablástól a házasságkötésig 50-51.
} 
separate property, which the widow had to receive from her husband's assets prior to other claims. ${ }^{8}$ As it was mentioned before, there were two kinds of dos in national customary law. The woman could claim the dos legalis in the event of becoming a widow, even if she did not have a prior agreement. On the contrary, dos contractualis was ensured to the wife on the basis of a separate provision of the husband's free will, and this also typically became valid after the husband's death. István Cqövek reviewed the earlier decisions and jurisprudence of the Royal Curia in his collection Planum tabulare published in 1825, on the basis of which he also summarized the rules of the dos. According to this summary, if the judge believed that the wife had given cause to the divorce, she lost her dos. However, the termination of cohabitation in itself did not have such a consequence. If, in turn, the husband was declared responsible for the divorce, he was obliged to pay the dos. The woman could only lose her dos due to her own fault, mainly due to adultery. ${ }^{9}$ Until the second half of the $19^{\text {th }}$ century, most authors discussed the dos the most elaborately among all legal institutions of property law by presenting the resources and the jurisprudence. ${ }^{10}$

Besides the dos, dowry also played a prominent role in Hungarian customary law over time. The woman was endowed by her family with her own property, the dowry, or the so called trousseau. The amount of the dowry depended on the woman's rank and financial position. Its purpose was to contribute to married life, so the dowry was meant as support to cover the costs of the couple's life. According to Hungarian feudal law, only movable goods could constitute dowry. Later it could be any profitable movable or immovable property, even money. Giving dowry was not compulsory. At the same time, it can be stated that different types of wedding gifts were the means of establishing a closer relationship between the families of the married couple, so even if it was not obligatory to give a dowry, it was a widespread institution nevertheless. ${ }^{11}$ In the case of the dowry, a double legal relation arose: the husband had usufruct over the dowry, and it was the limited property of the wife. So the dowry was the separate property of the wife, which was handled by her husband during the marriage. In the case of divorce, the husband was obliged to return the dowry to his wife. In old Hungarian society, the husband had to provide for his wife adequately with respect to her rank and financial position, regardless of whether he had received a dowry to compensate the obligation of maintenance. ${ }^{12}$

The wedding gift also evolved from the ancient habit of the purchase of women, and meant movable goods that the groom or the parents of the spouses or anyone else gave to the spouses, but typically to the bride at the time of the engagement or wedding. After the marriage, it was considered the separate property of the wife, and she could not lose it either in the case of adultery, or incestuous marriage. In cases when the marriage was cancelled, the groom could claim back the wedding gift only if the engagement broke up due to the bride's fault. Like in the case of the dos, the woman could freely make her will regarding the wedding gift. ${ }^{13} W$ erbócsy stated in his Triple Book (Tripartitum) that if the wife died without having a child, the relatives of the woman were entitled

\footnotetext{
8 MEZEY, Magyar jogtörténet 68-69.

${ }^{9}$ CZÖVEK, Planum tabulare 288.

${ }^{10}$ Herger, A törvényes és az írott hitbér Baranyában 1848 után 140.

11 SZŐCSNÉ GAZDA, A háromszéki hozomány a 19. században 23-26.

12 BALOGI, A hozomány szabályozása a korábbi magyar magánjogban 4-8.

${ }^{13}$ Hungarian Catholic Lexicon, wedding gift.
} 
to the wedding gift provided by the parents to the bride. However, if the husband died, the wife was entitled to the gift. ${ }^{14}$

The last Hungarian Feudal National Assembly enacted the so called April Laws in 1848 that transformed Hungary from a feudal state to a parliamentary state, and launched the formation of the middle-class. Law XV of 1848 abolished aviticity, and stated that the ministry would develop a civil code ( $(\mathbb{1})$. However, due to the defeat of the Revolution and the War of Independence of 1848-49, the drafting of the Code was not realized. The Austrian Civil Code (ABGB) was introduced in Hungary in 1853 and was in force until 1863; however, its provisions were not implemented completely, and its scope did not extend to every area. ${ }^{15}$ Despite the fact that the ABGB was only temporarily and partially valid, it was the first modern civil law code in Hungary that had an impact on later legal practice. ${ }^{16}$ The main institution of the ABGB's matrimonial property law was the dowry, which, in terms of its purpose, was identical to the concept of the dowry in Hungarian practice: the woman brought it to the marriage to contribute to the costs of it. However, according to the ABGB, dowry was an obligation and had to be provided by the girl's family. There was a significant difference compared to Hungarian law: the husband not only had usufruct over the dowry, but also possessed proprietary rights over it. The dowry had to be returned only in case of the husband's death, normally to the woman, or in the event of her death, to the heirs, or if it was provided by a third person, he or she could arrange the dowry to be returned to $\mathrm{him} /$ her. In addition to the dowry, the ABGB also defined three different forms of gift, but none of them matched the Hungarian wedding gift. The husband could give jewellery to his wife, or the spouses could give several benefits to each other, and beyond these the so called Morgengabe was given to the wife after the consummation of the marriage. ${ }^{17}$

After the Austro-Hungarian Compromise of 1867, Hungarian codification could begin. The draft on matrimonial law was discussed by the Parliament for years, and several points of it were the subject of intense debate during the legislative process. Finally, Act XXXI of 1894 was accepted in December, 1894. For the first time, it created a uniform marriage law and state judiciary for the whole country in matrimonial matters. Act XXXI also introduced the obligation of civil marriage. ${ }^{18}$ Regarding matrimonial property law, the new regulation took as a basis that the woman could freely dispose of her property. It names neither the dowry nor the dos explicitly, but it clearly refers to them in the section on the dissolution of marriage. It can be claimed that the first Hungarian act in matrimonial law judged married women much more favourably than the laws of other European countries at the time. For instance, it did not distinguish between a male and a female adulterer.

Several drafts of the Civil Code were created in the first half of the $20^{\text {th }}$ century. The first text was published in 1900, the second in 1913, and finally the fifth, the proposal for a Hungarian Civil Code, was presented to Parliament in 1928. However, none of them came into force. Nonetheless, they had a great impact on judicial practice and launched a broad social dialogue in which the feminist movements were already involved. Each draft described in detail the regulation

\footnotetext{
14 SZŐCSNÉ GAZDA, A háromszéki hozomány a 19. században 23-26.

15 BÉLI, Magyar jogtörténet. A tradicionális jog 194.

16 PŐDÖR, Az Osztrák Polgári Törvénykönyv 24.

${ }^{17}$ Herger, A hozomány szerepe a magyar vagyonjogi fejlődésben 195-196.

18 MEZEY, Magyar jogtörténet 118.
} 
of dowry and treated it as an independent legal institution. The drafts strictly separated the woman's separate property and the dowry from each other: the dowry was the property of the woman for the benefit of the husband, and this was different from the woman's separate property. ${ }^{19}$ It was stipulated that the amount of the dowry must be recorded in a notarial deed, and created the concept of usufruct over the dowry for the husband. ${ }^{20}$ The essence of this concept was that the usufruct of the dowry was not a license of free disposal of the husband, since the dowry explicitly could only be spent on the expenses of married life. The 1928 Proposal of the Civil Code stated that usufruct over the dowry lasted until the end of the marriage, and the husband had to pay it back in case of divorce. ${ }^{21}$ In addition to the dowry, the draft also devoted a separate chapter to the regulation of the dos contractualis. It should be emphasized that the draft only accepted the dos contractualis, which had to be recorded in a notarial deed to be valid. ${ }^{22}$ Thus the dos legalis was removed from the draft. In general, the drafts handled the relationship between spouses as a mutual partnership: the husband had the unilateral obligation to maintain the family, but at the same time the wife was responsible for managing the common household. ${ }^{23}$

Compared to traditional Hungarian matrimonial property law, the first significant change was Act XII of 1946 on the Elimination of the Effects of Certain Rules of Matrimonial Property and Succession Law Arising from the Discrimination of Ranks, which eliminated the institution of dos legalis. According to Esater Cs. Herger's research, this was a well-founded step, because by that time the dos was only a historical legal institution and had lost its former significance. The dos was to be rewarded to the faithful wife at the end of the marriage, so it lost its meaning in a society where the lack of marital loyalty led the reasons leading to divorce. ${ }^{24}$ In the explanatory memorandum of Act XII of 1946 it is also included that according to the practice of the judiciary, dos contractualis was not accompanied by dos legalis, even if the husband left more to his wife than the sum of the dos legalis. On the other hand, it points out that the provision does not affect the scope of regulations on the dos contractualis. ${ }^{25}$

The first comprehensive codification of Hungarian family law occurred in the Act IV of 1952 on Marriage, Family and Guardianship. ${ }^{26}$ The Act of 1952 already treated spouses as fully equal parties, so it declared that the rights and duties of the spouses were equal. ${ }^{27}$ Thus it did not mention either the dowry of the woman, or the dos contractualis of the husband, since both legal institutions explicitly referred to the responsibilities of the wife or the husband. The IV Act of 1986 allowed the spouses to enter into a marriage contract before the marriage to settle their property relations, so they could determine which part of their assets should go to the common and which to separate property. The Hungarian Civil Code in force today also includes the possibility of a matrimonial property contract. $^{28}$

\footnotetext{
19 TRunKOS, A házassági vagyonjog szabályozása 116.

${ }^{20}$ Draft of the Hungarian General Civil Code, First Text $₫ 112, \S 113$.

211928 Proposal of the Hungarian Civil Code $\ 137$.

221928 Proposal of the Hungarian Civil Code $\$ 162$.

231928 Proposal of the Hungarian Civil Code $\$ 113, \mathbb{1} 115$.

${ }^{24}$ Herger, A törvényes és az írott hitbér Baranyában 1848 után 163-164.

${ }^{25}$ Explanatory memorandum of the Act XII of 19465.

${ }^{26}$ WeISs, Az új Ptk. és a családjogi viszonyok szabályozása 4-5.

271952 Act IV on Marriage, Family and Guardianship \ 23.

${ }^{28}$ HEGEDŰs, Házassági vagyonjogi rendszerek 221-222.
} 


\section{Islamic marriage and the mahr}

In most of the Muslim world, since the $19^{\text {th }}$ century, the application of Islamic law has been limited to the area of family law. The principles of matrimonial and inheritance law in Sharia are incorporated into state law in almost all Muslim-majority countries. This is also a proof of the important role played by Islamic family and marriage law in Muslim societies.

On the basis of the records preceding Prophet Mohammed, it can be concluded that the practice of marriage in the Arabian Peninsula was based on matriarchal relationships, so the offspring were only kept count of on the female side. It was not a female-dominated social system, but there were extensive matriarchal households conducted by the older woman's brother. A woman could have more husbands: men did not live in the household of the woman, they only visited her. Due to this social system, the situation of women was similar to actual prostitution. At the time of Mohammed, the tribal social system began to collapse due to the flourishing trade in major cities such as Mecca. The wealthy traders wanted their own sons, not the children of their sisters, to inherit their wealth. A patriarchal social system evolved with the emergence of Islam: women could establish an intimate relationship with only one man, and within a household the husband, his wife or wives and their children lived together. The emergence of polygamy is linked to a specific historic event, the Battle of Uhud, when Mecca and Medina fought each other in 625 AD. In this battle, the Meccan killed many Muslim men. After the battle, in order to support the widows, Mohammed urged Muslim men to have more wives. ${ }^{29}$ Mohammed set an example with his own family: he took more women as wives, giving each of them her own home in his house. The following verse refers to the institution of polygamy in the Qur'an: "And if you fear that you will not deal justly with the orphan girls, then marry those that please you of [other] women, two or three or four. But if you fear that you will not be just, then [marry only] one or those your right hand possesses. That is more suitable that you may not incline [to injustice]". ${ }^{30}$ Polyandry probably completely ceased to exist after one or two generations. ${ }^{31}$ The Islamic law later developed on the basis of the Qur'an allows a man to have up to four wives, a woman, however, can only have one husband at a time. The man's duty is to treat all his wives equally. Nowadays, the law of several Muslim countries (e. g. Turkey, Tunisia) explicitly prohibits polygamy.

Marriage according to the Sharia is a contractual relationship from which specific rights and duties derive. In many cases, a guardian (vali) acts on behalf of the woman, while the man represents himself. The vali could be the closest male relative of the bride, consequently her father, her grandfather on her father's side, her son, her brother or her uncle. One of the essential elements of a valid Islamic marriage contract is the determination of the mahr. ${ }^{32}$ Marriages without a mahr are automatically voided. The groom or the groom's father or his family is obligated to give the mahr to the bride on the occasion of the marriage. The purpose of the mahr is to provide the woman with financial independence primarily in case of her husband's death or divorce, because the Sharia is not familiar with the concept of matrimonial community of property. Thus any property brought

\footnotetext{
${ }^{29}$ WATT, Az iszlám rövid története 109-113.

${ }^{30}$ Quran 4:3

31 WATT, Az iszlám rövid története 109-113.

32 HEKA, Vallási jogrendszerek 299-305.
} 
by a party to the marriage remains the property of that person, and any property acquired during the marriage is the sole property of the person who acquired it. The principles of the mahr were already laid out in the Qur'an, and the instructions for its degree were written in the Hadith. It is disputed whether the practice of the mahr had already existed among the pagan Arabs, or it can be seen as the revolutionary innovation of the Qur'an. In any case, the institution of mabr included in the Qur'an undoubtedly gave women greater rights and provided them with financial security and independence. In practice, mahr is usually money, but it can be any movable or immovable property or even pledge or just a promise. Ibn Hanbal, the founder of one of the Islamic law schools, accounted of the story in which Prophet Mohammed married off a woman to a man who had no tangible assets, and could only offer to his future wife to teach her some verses of the Qur'an as mahr. In another hadith, Mobammed released one of his wives from slavery, which corresponded to his mahr. The degree of the mahr depends on the social and financial situation of the woman's family. What is considered a decent wedding donation is what other women in the family received earlier. This is why it could be a problem even nowadays if someone gets a very high mahr in the family, because later it is much harder to endow the family's unmarried daughters. ${ }^{33}$ The bride often receives the mabr in two parts. She gets the first part upon signing the marriage contract. This is the so called muqaddam, the prompt mahr which is the exclusive property of the wife even during the marriage, and she can spend it on whatever she wants. The second part of the mahr, called the mu'akbar, is a deferred and promised amount also involved in the marriage contract, and can be paid at any agreed upon date following the consummation of the marriage. The deferred mabr is usually a greater amount than the prompt one, because the deferred mabr is for the livelihood of the woman at the time of her husband's death or after divorce. The Hanafi and Maliki schools of Islamic jurisprudence forbid the postponement of the payment of the full mahr, and at least half of it must be paid at the time of the marriage. ${ }^{34}$ The husband can only accept any gift from his wife's family if he has already paid the mahr. Paying the mahr is the husband's absolute religious duty. For example, in Iran imprisonment can also be imposed on a husband who has not paid the mahr for his wife.

In contrast to the indissoluble bond of Catholic marriage, Islamic law allows divorce, which was also common in the Islamic world earlier. According to the Sharia, divorce can take place in several ways. The husband can unilaterally declare his intent to divorce (talaq), which he does not need to justify. In case of a talaq divorce the husband has to pay the whole amount of the deferred mahr. If the woman wants to divorce her husband, she has two options. In the case of tafriq, she has to have a strong reason: abuse or abandonment. In this case, the intervention of a qadi (religious judge) is also necessary for separating the spouses, and if the divorce is pronounced, the man is also obliged to pay the full amount of the mahr. Another possibility for a woman to divorce is known as khul. This type of divorce is performed by mutual agreement, so there is no need for a specific reason and for the judgment of a qadi. In this case, however, the woman is usually forced to give up some or all of her mahr. ${ }^{35}$ According to the Hanafi and Maliki schools, women do not

\footnotetext{
${ }^{33}$ IVÁNYI, A törvény (šarī‘a) az iszlámban 87-88.

${ }^{34}$ SPENCER, Mahr as Contract 8.

35 OMAN, Bargaining in the Shadow of God's Law 589-592.
} 
have to give up their mahr in case of kbul divorce either. The husband only has to pay half of the mahr if the spouses decide to divorce before the consummation of the marriage. ${ }^{36}$

It is interesting to note that, according to the law of the Shiite Jafari school, it is possible to marry temporarily. This kind of marriage is called muta (pleasure) marriage. In the beginning, Prophet Mohammed allowed this ancient pre-Islamic Arab custom to survive in cases when Muslim men travelled for a long time or participated in campaigns. Muta marriage was contracted for a specific, short-term period of time, after which the man could continue his way if he paid the mahr for the woman. ${ }^{37}$

\section{Conclusions - similarities and differences}

In Hungarian customary law and in later codification, different wedding donations were present, the history of which goes back to the tradition of the Hungarians' conquering ancestors. The sacred sources of the Sharia, the Qur'an and the Hadith have made the mahr an indispensable and perennial legal institution, an essential element of marriage under Islamic law. By the middle of the $20^{\text {th }}$ century, Hungarian legal development and social order got to a point where the spouses were considered to be equal in all their rights. That is why the Marriage Act of 1952 did not draw any specific obligations or rights either for men or for women. In the past, however, the dos, the dowry and the wedding gift all played a central role in Hungarian marriage law.

Unlike the mabr, the dowry was not given by the groom, but by the family of the bride as support for covering the costs of married life. At the same time, during and after the marriage, it was considered to be the woman's separate property, while the husband only had usufruct over the dowry and had to give it back to the woman if the marriage ended.

The most frequently discussed legal institution over the centuries was the dos, which was the loyal wife's claim to the property of her husband in the event of the termination of marriage. Similarly to the mabr, the dos also strengthened the position of the wife in terms of property law. It was also the separate property of the woman and she got it after the death of her husband, ahead of other demands, like the Muslim wife got the mabr. The husband separated the dos contractualis from his own property for his wife as a result of exercising his free will, so it was an optional act, not like in the case of the mahr, regarding which the Islamic law imposes an obligation. However, the wife was entitled to get the dos legalis automatically, as in the case of mahr. According to the Sharia, the wife has to give up on her mahr if she initiates a khul divorce, so she is the one wanting to separate from her husband without any special reason. She also loses her mahr if she was the guilty party, for instance if she committed adultery. ${ }^{38}$ The Hungarian wife also lost her dos if - according to the verdict of the judge - she was responsible for the divorce.

It was only in 1946 that the dos legalis was legally eliminated, yet in the explanation of the Act it was emphasised that by then, the dos had become a historical legal institution and dropped out of jurisprudence. Although this provision did not deal with dos contractualis, it had also lost its significance by then. On the one hand, it is in favour of the mabr that it legally and economically

\footnotetext{
${ }^{36}$ HEKA, Vallási jogrendszerek 304-305.

${ }^{37}$ HiLLENBRAND, Az iszlám 166.

${ }^{38}$ HEKA, Vallási jogrendszerek 305.
} 
strengthens the position of the woman who is the more vulnerable party in the marriage, but on the other hand it can also be observed that in today's modern society it is less indispensable and has begun to lose its former foundation. This ambivalence is also the basis of the feminist discourse on the topic. As one of the Muslim wife's responsibilities is to accept her husband's sexual approach, the mahr is often interpreted as buying the woman's sexuality or virginity. Others are of the opinion that the mabr contributes to the preservation of the patriarchal structure of Islamic law and to the maintenance of gender inequalities. ${ }^{39}$

\section{Bibliography and sources}

Draft of the Hungarian General Civil Code, First Text = A Magyar Általános Polgári Törvénykönyv Tervezet, Első szöveg. Budapest 1900

https://ia801408.us.archive.org/3/items/amagyarltalnosp00hunggoog/amagyarltalnosp00hunggoog.pdf (2019. 08. 08.)

Proposal of the Hungarian Civil Code = 1928. évi magánjogi törvényjavaslat, Magyarország Magánjogi Törvénykönyve. Budapest 1928

https:// net.jogtar.hu/ezer-ev-torveny?docid=92800000.TVJ\&searchUrl=/ezer-ev-torvenyei\%3Fpagenum $\% 3 \mathrm{D} 52$ (2019. 09. 01.)

Explanatory memorandum of the Act XII of 1946 = 1946. évi XII. törvénycikk indokolása

https:// net.jogtar.hu/ezer-ev-torveny?docid=94600012.TVI\&searchUrl=/ezer-ev-torvenyei $\% 3$ Fpagenum $\% 3$ D 51 (2019. 09. 01.)

1952 Act IV on Marriage, Family and Guardianship = 1952. évi IV. törvény a házasságról, a családról és a gyámságról http://www.njt.hu/cgi_bin/njt_doc.cgi?docid=308.222315 (2019. 09. 01.)

BALOGI Zsófia: A hozomány szabályozása a korábbi magyar magánjogban — a hagyományozott hozomány kettős jogi természete és kapcsolata az új Ptk. által szorgalmazott halál esetére rendelkező szerződéssel. Themis, 2010 december, 4-13. http://epa.oszk.hu/02300/02363/00014/pdf/ (2019. 08.08.)

BÉLI Gábor: Magyar jogtörténet. A tradicionális jog. Budapest - Pécs 2014

https://www.tankonyvtar.hu/hu/tartalom/tamop425/2011_0001_528_Beli_Gabor_Magyar_jogtortenet/ch01.html \#id500805 (2019. 08. 16.)

CzÖvEK István: Planum tabulare, vagy a kir. curiának végzései melyeket ama boldog emlékezetú Maria Theresia császárné és Magyarország királynéja rendbe szedetett 1769. eszt. most pedig magyar nyelven kiadta. Buda 1825

HEGEDỨs Andrea: Házassági vagyonjogi rendszerek az új Ptk.-ban. In: SÁPI Edit (ed.): Decem anni in Europaea Unione III. Miskoc 2015, 217-236.

http://jogikar.uni-miskolc.hu/projectSetup/files/polgari/pottitkos/pot/9pot20132014tanulmanykotet.pdf (2019. 08. 10.)

HEKA László: Vallási jogrendszerek. Szeged 2012

HERGER Csabáné: A hozomány szerepe a magyar vagyonjogi fejlődésben. Jogtudományi Közlöny 2016/4. sz. 193203.

HERGER Csabáné: A modern magyar házassági vagyonjog kialakulása és rendszere a német jogfejlődés tükrében, Passau 2017

HERGER Csabáné: A törvényes és az írott hitbér Baranyában 1848 után. In: NAGY Janka Teodóra (ed.): Szokásjog és Jogszokás I., Szekszárd 2016, 139-164.

HiLlenBRAND, Carole: Az iszlám. Új történeti bevezetés. Budapest 2016

Hungarian Catholic Lexicon, Kidnapping of Women. (Magyar Katolikus Lexikon, leányrablás szócikk.) http://lexikon.katolikus.hu/L/le\%C3\%A1 nyrabl\%C3\%A1s.html (2019. 08. 05.)

\footnotetext{
39 SPENCER, Mahr as Contract 7.
} 
Hungarian Catholic Lexicon. Wedding Gift (Magyar Katolikus Lexikon, jegyajándék szócikk.) http://lexikon.katolikus.hu/J/jegyaj\%C3\%A1nd\%C3\%A9k.html (2019. 08. 05.)

IVÁNYI Tamás: A törvény (šarī'a) az iszlámban. Budapest 2008

LOUTFI Anna: A Magyar családjog és a nemi hierarchiáért folytatott harc 1848-1913. Eszmélet, 2007/73. 59-80. http://www.eszmelet.hu/loutfi_anna-a-magyar-csaladjog-es-a-nemi-hierarchiaert-folyt/ (2019. 07. 25.)

MALINOWSKI, Bronoslaw: A Scientific Theory of Culture and Other Essays. New York 1944

MEZEY Barna (ed.): Magyar jogtörténet. Budapest 2004

https://www.tankonyvtar.hu/hu/tartalom/tamop425/2011_0001_520_mezey_magyar_jogtortenet/adatok.html (2019. 08. 25.)

NAGY Janka Teodóra: A nőrablástól a házasságkötésig. In: GYÖRGYI Erzsébet (ed.): Lakodalmi szokások. Budapest 2001, 49-53.

https://www.academia.edu/5368882/2001_A_n \%C5\% 11 rabl\%C3\%A1st $\%$ C3\%B31_a_h\%C3\%A1 zass $\%$ C3\%A1gk $\%$ C3\%B6t\%C3\%A9sig (2019. 08. 08.)

OMAN, Nathan B.: Bargaining in the Shadow of God's Law: Islamic 'Mahr' Contracts and the Perils of Legal Specialization. In: Wake Forest Law Review, 2010/Vol. 45, 579-606.

http://wakeforestlawreview.com/wp- content/uploads/2014/10/Oman_LawReview_072010.pdf (2019. 08. 17.)

PŐDÖR Lea: Az Osztrák Polgári Törvénykönyv, Győr 2012

https://jogtortenet.sze.hu/images/dokumentumok/tanulm\%C3\%A1 nyok/Podor\%20Lea\%20-\%20OPTK.pdf (2019. 08. 07.)

Qur'an https://quran.com/?local=en (2019. 08. 14.)

SPENCER, Katherine: Mahr as Contract: Internal Pluralism and External Perspectives. In: Oñati Socio-Legal Series, 2011/Vol. 1, No. 2. https://papers.ssrn.com/sol3/papers.cfm?abstract_id=1898527 (2019. 08. 14.)

SZŐCSNÉ GAZDA Enikő: A háromszéki hozomány a 19. században. Szentendre 2015

TRUNKOS Anita Krisztina: A házassági vagyonjog szabályozása a magyar általános polgári törvénykönyv 1900-as tervezetében. In: Publicationes Universitatis Miskolcinensis. Sectio Juridica et Politica, 2014/Tomus 32, $113-131$. https://matarka.hu/cikk_list.php?fusz=125995 (2019. 08. 14.)

WATT, William Montgomery: Az iszlám rövid története. Budapest 2000

WeIss Emília: Az új Ptk. és a családjogi viszonyok szabályozása. Polgári Jogi Kodifikáció, 2000/2. 4-5. https://ptk2013.hu/wp-content/uploads/2012/11/2000-2PJK.pdf (2019. 08. 07.) 